\title{
Austerity as a global prescription and lessons from the neoliberal Baltic experiment
}

\author{
Jeffrey Sommers, Charles Woolfson and Arunas Juska
}

\section{Linköping University Post Print}

\section{Tweet}

N.B.: When citing this work, cite the original article.

Original Publication:

Jeffrey Sommers, Charles Woolfson and Arunas Juska, Austerity as a global prescription and lessons from the neoliberal Baltic experiment, 2014, Economic and Labour Relations Review, (25), 3, 397-416.

http://dx.doi.org/10.1177/1035304614544091

Copyright: (C) The Author(s) 2014

http://elr.sagepub.com/

Postprint available at: Linköping University Electronic Press

http://urn.kb.se/resolve?urn=urn:nbn:se:liu:diva-109017 
Austerity as a global prescription and lessons from the neoliberal Baltic experiment

Jeffrey Sommers

University of Wisconsin-Milwaukee, USA

Charles Woolfson

Linköping University, Sweden

\author{
Arunas Juska \\ East Carolina University, USA \\ Corresponding author: Professor Charles Woolfson, REMESO, Linköping University, \\ SE-601 74, Sweden. Email: charles.woolfson@liu.se
}

\begin{abstract}
This article analyses the 2008 economic crisis and its outcomes for the Baltic states. It locates the causes of the crisis in the slow economic growth that began just prior to the demise of the Bretton Woods system in the 1970s. This article then gives a genealogy of European economic policy responses to the crisis, tracing them from the emerging 'freshwater' school of economics (e.g., University of Chicago, et al.) that arose in opposition to Keynesian theory. The more immediate cause of the 2008 crisis, long in the making, was its reliance on private debt to sustain economic demand in lieu of profit enhancing wage suppression. Following the 2008 financial shock, EU policymakers crafted policy that placed the burden of adjustment on labour. A program of austerity was chosen in much of the EU, at odds with the post-war European 'social model'. This represented a retreat from the notion of a European project that encouraged liberalization of economic policy but at the same time could be harmonized with a social dimension to create a distinctive 'Social Europe'. Nowhere was this austerity more vigorously applied than in the Baltic states. Its effects are examined here, along with lessons to be derived from that experience.
\end{abstract}

JEL Codes: P16; P46; Z18

Keywords Global financial crisis; labour standards; migration; neoliberalism 
Just as any revolution eats its children, unchecked market fundamentalism can devour the social capital essential for the long-term dynamism of capitalism itself.

Mark Carney, Governor of the Bank of England, speech at the Conference on Inclusive Capitalism, London, 27 May 2014.

\section{Introduction}

In May 2014, gracing the platform of a conference on 'Inclusive Capitalism' alongside Mark Carney, Governor of the Bank of England, Christine Lagarde, Managing Director of the IMF, wrestled with the oxymoron of the conference title (Lagarde, 2014). 'Trust, opportunity, rewards for all within a market economy - allowing everyone's talents to flourish. Certainly, that is the vision', said Lagarde. In a somewhat darker vein, Lagarde continued:

Most recently, however, capitalism has been characterized by 'excess' - in risk-taking, leverage, opacity, complexity, and compensation. It led to massive destruction of value. It has also been associated with high unemployment, rising social tensions, and growing political disillusion - all of this happening in the wake of the Great Recession (Lagarde, 2014).

Such introspection would have been almost unthinkable a decade or so before (Bernanke, 2004; Glassman and Hassett, 1999; Lopez, 2013). But amidst the mea culpas for previous excesses, there was little to suggest that the favoured formula for resolving the crisis, the imposition of global austerity via the suppression of wages and massive cuts to public sector expenditures, needed to be rethought. Within days of this august gathering in London, Joe Hockey, the Australian's government's current Treasury minister, unabashedly reiterated 'the end of the age of entitlement', proposing arguably the harshest austerity budget in the country's history (Hockey, 2014). Thus, while the shock of the financial crisis may have caused momentary introspection, even amongst the most ardent proponents of financialisation (Geithner, 2014), this ephemeral period of uncertainty did not inhibit some politicians, and the economists and policymakers who serve the, from ascribing the system's failure to insufficient vigour in pursuing previous neoliberal policies against public debt and neglect of fiscal rectitude (Reinhart and Rogoff, 2010; Ryan, 2012). In short, what was required, and the Australian government's budgetary proposals were by no means exceptional, was more of the same medicine of 'growth-friendly fiscal consolidation' as proposed by the leading institutions of international capitalism (Cournède et.al., 2013) and even more still, of the tried and trusted accompanying formula of structural reforms to induce greater labour market 'flexibility'.

Given the magnitude of the 2008 collapse, at first blush this seems a curious response. Indeed, the great Swedish heterodox economist, Gunnar Myrdal, observed the same pattern on the cusp of the last great economic crisis in 1929. In that year, Myrdal reminded us, economic theory was not developed in an interest-free vacuum, but rather, as he put it in his book title published in 1929, there was The Political Element in the Development of Economic Theory (Myrdal,' 1990). At the very end of Myrdal's career in 1974 he was awarded the Nobel in economics (ironically shared with his philosophical free-market nemesis, Milton Friedman), precisely at a moment when the world economy 
was about to reorganised along lines of wage suppression and financialisation that would create the conditions for the contemporary reprise of 1929.

Heterodox economists point out that in the run up to the crisis, insufficient consumer demand resulted from stagnant wages in many of the world's advanced economies. Alternating cycles of private and public debt since the 1980s moreover permitted the purchase of goods and services the economy could produce, while wages no longer kept pace with economic growth (Streeck, 2011; Piketty, 2014). This system of a credit-sustained economy was and is hugely profitable for the financial sector. Wholesale debt write-downs and a restoration of wage growth commensurate with the economy's underlying growth would threaten the profits of the financial sector. For example, in the United States finance comprised 15\% of corporate profits for much of the 1970s. This dipped to $10 \%$ in the early 1980s. Then, with financialisation, finance comprised an ever-larger sector of corporate profits, reaching a full $40 \%$ by 2007 (the year before Wall Street's collapse). Meanwhile, finance supplied only $15 \%$ of corporations' gross value added wealth to the economy and only $5 \%$ of all private sector jobs (The Economist, 2008). Given this massive growth in the size and power of global finance as a share of GDP (Gudmundsson, 2008), 'de-financialising' the economy, while discussed after the 2008 crisis, was not selected as an option for a way out of the crisis, or even as a precondition for restoring sustainable economic growth in the 'real economy' (Panitch, 2009).

In Europe, as austerity was implemented in the UK, Ireland, Spain, Italy, Greece, Portugal and later France, the results, on the whole have ranged from disappointing at best to disastrous at worst. -Yet, 'exit' from the crisis, has proved tentative and uncertain, not only in the Eurozone countries, but in the advanced capitalist economies in general. Somewhere there needed to be a clear case, illustrating that 'pain' meant 'gain' in order to justify resolving the crisis on neoliberal terms. It was in this context that purported exemplars of 'successful' austerity were seized upon. The Baltic states of Estonia, Latvia and Lithuania collectively have provided a modern morality tale of adversity overcome and fiscal rectitude restored, through resolve and thrift, and thus offered defenders of the status quo a convenient myth-in-the-making.

Having experienced the most sudden and severe economic downturn during the crisis in global terms, these three small countries had now restored economic health through a series of radical measures known as 'internal devaluation.' The strategy of internal devaluation is merely the inverse of restoring competiveness through the traditional method of currency devaluation. Both types of devaluation reduce the consuming power of the public. Internal devaluation achieves this by cutting wages across the board. Currency devaluations cut the purchasing power of consumers by making the national currency weaker and thus foreign goods more expensive. This has the virtue of increasing consumption of domestically produced goods, while making exports cheaper. Currency devaluations also have the virtue of delivering faster price adjustment, ergo faster recoveries (Wood, 2013). Currency devaluation, however, had disadvantages in the Baltic context. It would have raised the cost of euros against local currencies in the Baltic states. The euro was the currency required for most loan repayments to the Swedish banks that held most of the Baltic commercial and residential mortgages. External devaluation would have increased defaults on those eurodenominated loans, thus causing a Swedish banking crisis that would, in turn, have 
compromised fatally the chances for the Baltic states to make a future successful bid to join the euro, not to mention placing at risk the stability of Scandinavian banks, with the possibility of a spillover into and even 'contagion' across the entire European financial sector (Sommers and Woolfson, 2014).

The myth of 'successful' Baltic austerity was to become all the more potent as labour resistance to austerity mounted in other parts of Europe. Unlike their crisisstricken southern Europe counterparts, prone to general strikes and civil commotion, or pots and pans protests as in Iceland, the Baltic populace appeared to offer no sustained opposition to austerity, to the delight of the business press (Forbes, 2010). Instead, a supposedly mature electorate had stoically taken the austerity medicine imposed upon them and come out the other side with renewed vigour. The lessons of radical austerity and internal devaluation drawn from the Baltic experience therefore resonated well beyond the confines of these three small states, the combined population of which is no more than that of New South Wales. That said, the Baltic austerity story has had profound appeal.

Indeed, this communal hymn-singing by the international financial community has resulted in the Baltic states' prime ministers being feted at international conferences and invited to give keynote lectures in universities and policy institutes, where their determination to correct fiscal imbalances, even at the cost of imposing significant economic and social pain on the mass of their populations, is pointed to as the path for other wayward and 'profligate' European states to follow. A pantheon of figures including the ubiquitous Christine Lagarde, Anders Aslund, of the Peterson Institute in Washington, and Latvia's former austerity Prime Minister, Valdis Dombrovskis, along with many others in the financial press, have lauded the success of radical austerity policy prescriptions in the Baltic states (see for example Aslund and Dombrovskis. 2011).

Following 2010, macro-economic performance of the Baltic states seemed to support the effectiveness of austerity policies, especially in terms of the recovery of GDP. However, the realities and the wider implications of 'internal devaluation' for Europe's 'Social Model' (balancing unrestrained market forces by a 'social dimension'), are somewhat more complex. These are only revealed when the full price of the Baltic austerity path and its unique structural features are examined outside the realm of ideology and partisan interest. Our goal is to outline the fundamental overall trends rather than discuss in depth each aspect of austerity impacts, but by 2014 some definitive conclusions can be drawn as to the 'success' or otherwise of the Baltic model of austerity (For more details, see Sommers and Woolfson, 2014). The article proceeds as follows: first, the backdrop to the crisis in the global economy is briefly examined. Next, the broader 'neoliberal turn' is identified in the shift from Keynesianism to the importation of US-style 'freshwater economics' into European policy circles. Thereafter, contemporary hagiography of the Baltic model is analysed. The article concludes by suggesting why austerity in general, and a Baltic austerity model in particular, may have harmful economic and social consequences for the longer-term sustainability of future economic recovery of countries which follow this example.

\section{Backdrop to the crisis}

The largest economic crisis since the Great Depression proved vexing. The contradiction of sustaining an economy built on wage suppression and debt could no longer be squared. The old solutions of deploying debt (both public and private) had reached their limit as a 
solution for supporting the economy, given the previous accumulation of debts became too large for consumers and the public sector to sustain. Private credit could not continue being extended to a population that has been paid roughly stagnant inflation-adjusted wages in major economies, such as the US since the 1980s (Stone, Trisi, Sherman \& Tren, 2014), and Germany since the 2000s until the 2008 crash (Flassbeck, 2012). Rising public debt levels presented the fear of future higher borrowing costs (e.g., raised yields on government bonds) that often result when government debts become too large. The response of the international financial community, European policy makers and national governments, appeared self-evident, namely that labour must shoulder the cost of creating the conditions for economic recovery.

This policy response is at the core of what we now call 'austerity.' As Mark Blyth (2013) points out, today's austerity amounts to a reconfiguration of labour's employment rights at the national level and a massive attack on social and living standards across the European continent. It has profound implications for the erstwhile existence of the more benign, if ambiguously contentious idea, of a 'Social Europe' advanced by Jacques Delors in the 1980s as an attempt to reconcile Europe's post-war 'Social Market' model with the perceived need to liberalise and integrate European economies (Jepsen and Pascual, 2005). Delors maintained that European countries could open and de-regulate their economies while simultaneously offering a measure of equity and protective welfare supports to its citizens, thus moderating the inequities unleashed by unbridled market forces as evinced in the United States (Whyman et al., 2012; Song, 2011; Hermann and Mahnkopf, 2010; Emmanuelli, 2005). Current austerity however has thrown into question the ultimate reconciliation of the inherent divergence between the market and the social.

Yet, even seemingly radical solutions applied to crises of capital can prove fleeting in their curative effects. Out of temporary resolutions, new heightened contradictions and crises inevitably emerge. The costs of these crises have been increasingly borne by labour as a continuation of a long-term neoliberal policy of wage suppression and culling of government benefits in a concerted roll-back of many of the social and economic gains of the post-war settlement (Brenner, 1998). Labour and capital no longer stand in mutual corporatist reconciliation, and the attempt to impose neoliberal austerity on labour and the public sector, has been conducted without the cloying social democratic inhibitions of 'social partnership'.

Why then the choice of austerity? By imposing austerity in the public sector, capital was freed to make debt service payments in the private sector from funds that otherwise would have gone to public services. In short, this was the means for the private sector to socialise the costs of its post-crisis bailouts in countries ranging from the United States to Latvia. Capital liberated itself from the additional tax burdens required to pay for resulting public infrastructure and services.

Public debt became an avatar representing economic crises generally. In reality, in Europe leading up to the 2008 crisis, only Greece had an appreciable public sector debt at roughly $105 \%$ of GDP, thus matching its private debt problems. It is singularly ironic to note that the Baltic states themselves had among the lowest rates of public debt in Europe during the run up to the crisis, with Estonia, Latvia and Lithuania in 2007 respectively at $3.8 \%, 9.0 \%$, and $16.9 \%$ (Figure 1). Similarly, Australia has relatively low-levels of public debt at present. Instead, the burden of crisis-resolution was to be offloaded onto the 
public sector and onto the broader society, a 'socialisation of risk' standing in sharp contrast to the 'privatisation of profits.'

In short, the economic plunge in the Baltic states was purely a result of a privatesector banking crisis (stimulated in the main by the inflow of European funds and a profligate private lending policy on the part of the dominant Swedish banks) which in the context of the global recession revealed the deeper structural underdevelopment of their respective economies. The crash in the Baltics was contingent on the global crisis, but was in itself a foreseen and foreseeable sui generis disaster waiting to happen, as we shortly explain. First however we offer a short excursion on the fundamental underlying shift in economic thinking which created the preconditions for neoliberalism's ideological ascendancy in a European context: the importation of US school of 'freshwater economics'.

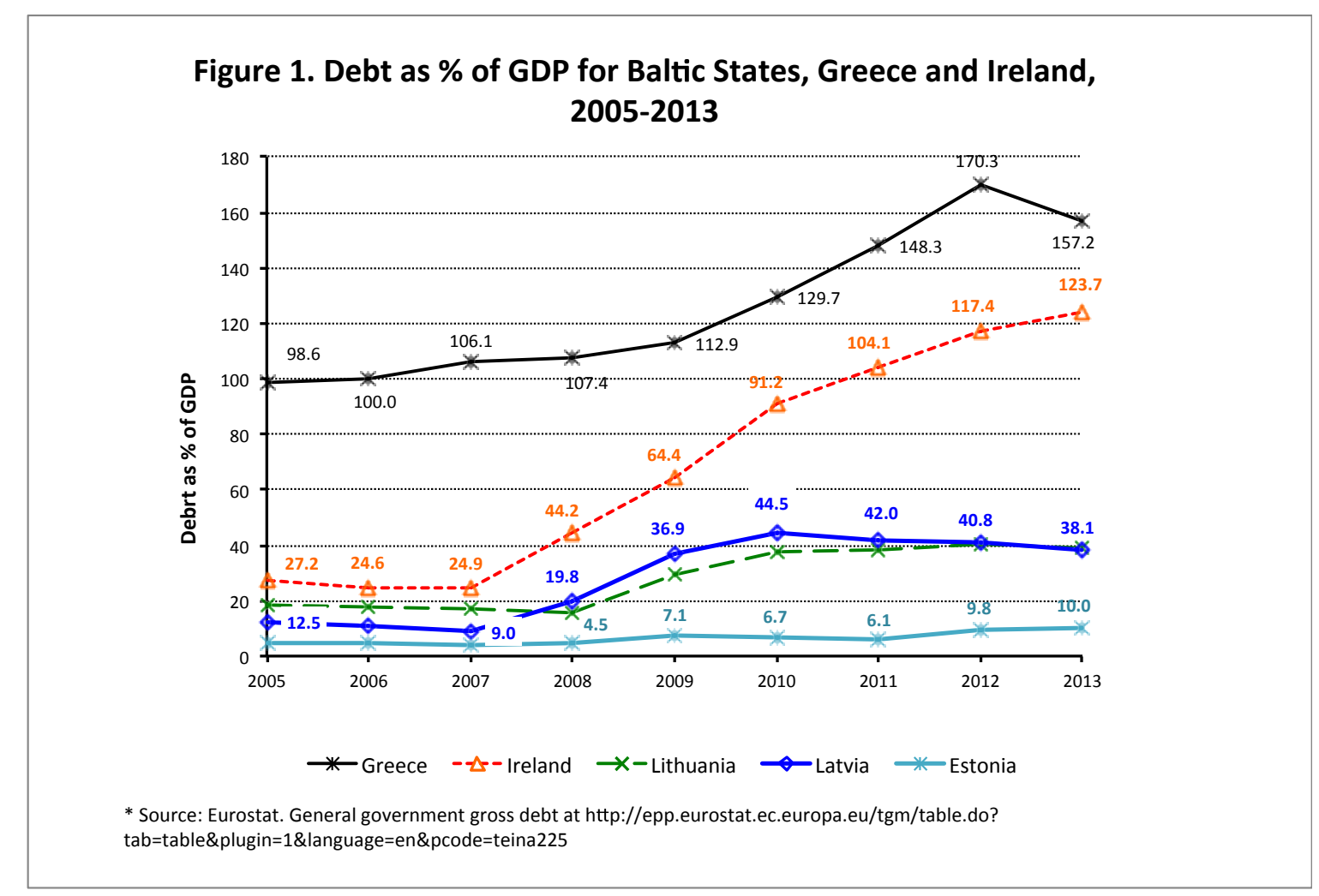

Freshwater economics, the 'neoliberal turn' and the demise of Social Europe

At the time of the 2008 crisis most observers of the EU still held an image of Europe as largely 'social democratic', and still maintaining adherence to some kind of social model, albeit in a reconciled form accommodating a more liberalised economy that could compete with US and East Asian capital. What was missed was the quiet revolution of sorts long underway among many of Europe's financial policymakers and economists. Among a growing number of them, the American 'freshwater school' of economics, a train of economic thought dominant by the Reagan years in the universities of the American Midwest, had displaced Keynesian models. Freshwater economics so-called, as propagated most conspicuously at the University of Chicago, held that counter-cyclical 
government spending during economic downturns made economic crises worse. In effect, this policy represented a rejection of Keynesian interventionism to mitigate business cycle downturns (Krugman, 2012: 101-10). The embrace of such thinking by economic policymakers marked the final act in a long drama begun with the opening scene of the Maastricht Treaty in 1992, which after 2008 saw the coup de grace delivered on much of the Social Europe model as austerity policies were imposed in many parts of the EU.

This recognition is important in order to understand why much of Europe chose austerity, and even more importantly, why they persisted with it to the point of obduracy in the face of its failures. The 2008 crisis made the long-time liberalising trends of European capitalism dating back to the Maastricht Treaty more visible. Post crisis, the EU accelerated its neoliberal turn in economic policy, with a commensurate de-emphasis on social policy. Europe had long been following US trends on economics and business organization since at least the 1970s (Panitch and Gindin, 2012). This Americanisation of economic policy and business organisation deepened during the 1980s in Germany and much of West Europe in the face of high unemployment and lacklustre economic growth. By comparison, the United States' relatively strong economic performance after the early 1980s looked attractive to European leaders. Viewed from the other side of the Atlantic it appeared as if it was economic liberalisation sui generis that drove the US economic recovery. In fact, much of the growth at the time was due to massive 'military Keynesian' policy (state sponsored arms production), the collapse in oil prices, and the peak of an unsustainable US dollar seigniorage.

By 1992 Europe had firmly set itself on the dual track of liberalisation and integration, beginning with the Maastricht Treaty and proceeding on that course through to the Lisbon Treaty of 2007. Its key features were a monetary union, which demanded that governments maintain strict limits on both annual deficits and total debt ratios to gross domestic product (GDP). Trade was liberalised within the context of an emergent single market. Later, as part of the drive to ensure fiscal prudence on the part of national governments, the Consolidated version of the Treaty on the Functioning of the European Union in Article 123 removed key elements of autonomy from national economic policy. Article 123 circumscribed the ability of national central banks to issue credit. From here on credit creation was to be primarily the provenance of private banks, thus ensuring them a rent (interest payments to banks and bondholders) for credit that central banks previously issued at no cost to themselves (See The Lisbon Treaty, 2008).

A related structural defect in the liberalized Europe was the inability to reconcile wage restraint designed to deliver higher corporate profits in the EU's more wealthy economies with their rising productivity. This policy created a deficit of demand (purchases of goods) in the economy. In the US this quandary was solved from the 1980s through to 2008 by the expansion of debt. US government debt tripled (more than doubled, inflation adjusted) under President Ronald Reagan, from $\$ 995$ billion in 1981 to nearly \$2.868 trillion (nominal) in 1989 (Office of Management \& Budget of The White House of the United States), with a debt to GDP ratio rising from $31 \%$ to $50 \%$ over the same period (Amadeo, 2013). When mounting public debts eventually unnerved bond markets, government deficits were driven down, followed by a switch to private credit thus fuelling US economic consumption in the 1990s. When finance in turn eventually tightened credit as private debts mounted, another round of public and private debt expansion followed in the early twenty-first century (Streeck, 2011). Thus it was in the 
EU as well, but with the emphasis more on private debt (Greece excepted). Private and some public debt would make up for the lack of wage restraint (pace the Americans) in much of Europe in the first decade of the twenty-first century. The central unresolved contradiction of wages lagging productivity in 'Old Europe' remained, with the inverse in 'New Europe'; productivity trailing wage growth. Thus, credit-fuelled consumption stoked by private lending and primarily based on property bubbles, finally collapsed in September 2008.

Complementing the issue of insufficient demand in the economy was the insufficient means for recycling capital between the richer and poorer nations that would be a necessary precondition for an EU monetary union. The chief challenge to such a monetary union was the different levels of productivity between the higher productivity of the older member states of the West and the newer, lower productivity members from the East (Sommers, 2011; Varoufakis, 2011). There were European Union Structural Funds that could recycle capital from rich countries to poorer ones, but those were insufficient in size to rectify fundamental differences in levels of economic development; and anyway did not apply to the recycling of private capital from richer to poorer countries. The only mechanism for doing so was lending, for which the euro enabled borrowing on the cheap by poorer countries to fund government deficits and to inflate real estate bubbles in the private sector. Cheap money (although with a private rent still extracted by banks and bondholders) allowed lower productivity countries to avoid increasing productivity by merely living off credit. This was enabled by the perceived low risk of sovereign debt and creditworthiness of the entire macroeconomic stability of the European Union (or more specifically Germany) embodied in the euro. By the time the crisis had migrated across the Atlantic, the European Commission (EC) and European Central Bank (ECB) economic policy management had fully internalized the American freshwater school of economics, thus dictating their response to the crisis itself.

\section{The Baltic Tigers and Baltic austerity}

On the surface at least, the newer EU member states of the East had no doubts about the benefits of European Union enlargement. For the aggressively neoliberal Baltic EU member states, the years following accession were marked by a surge in GDP growth, seemingly confirming an endless future vista of increasing prosperity for its populations. These high-growth years were heralded as the era of the celebrated 'Baltic Tigers'. During the years leading up to EU accession and in the three years that followed, average yearly growth of GDP exceeded $8 \%$ in Estonia and Latvia, and in Lithuania around $7.5 \%$, at a time when the EU27 average growth was less than $2.5 \%$ (Figure 2; also see Hübner, 2011). 
Figure 2. EU and Baltic GDP Growth Rates, 2005-2013

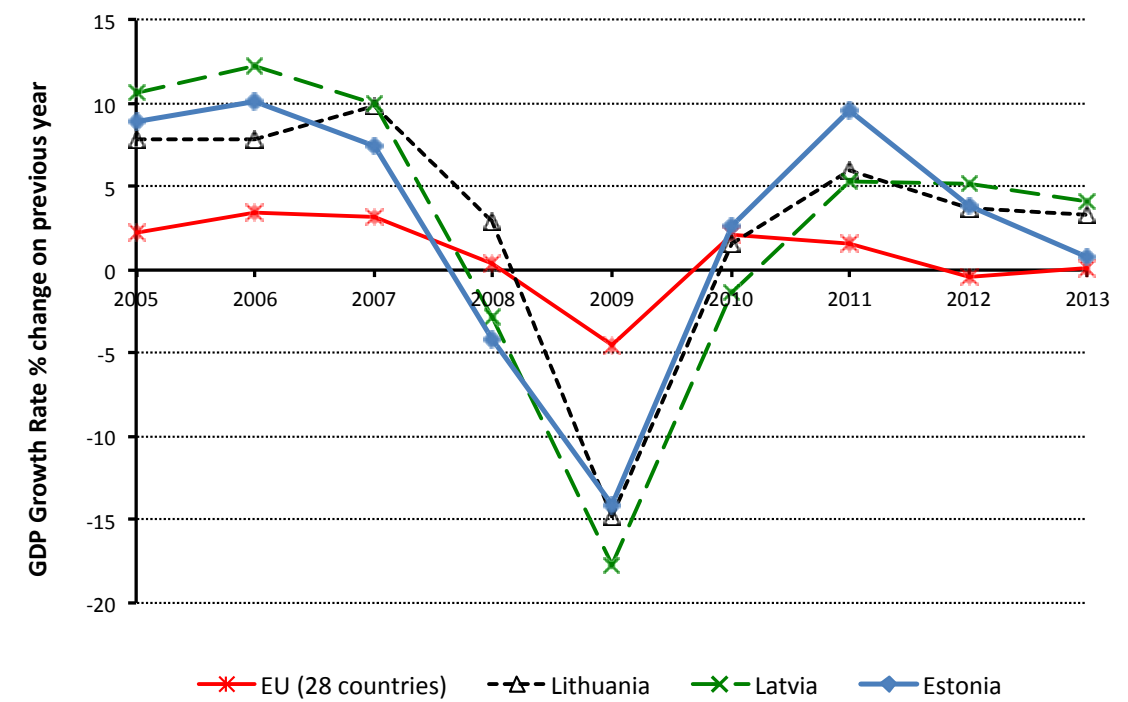

Source: Eurostat Real GDP growth rate - volume http://epp.eurostat.ec.europa.eu/tgm/table.do? tab=table\&init=1\&plugin=1\&language=en\&pcode=tec00115

A considerable portion of the tiger economies' 'success,' however, was driven by banks, many Swedish, pumping huge sums of unstable capital inflows, borrowed via the 'carrying trade' of cheap US and Japanese money designed to stimulate their own economies. Most of the money poured into the Baltic real estate markets. European Union Structural Funds further fuelled asset inflation. Property prices increased exponentially to the degree that per square meter cost in Vilnius exceeded that of Stockholm by 2007. An additional source still was hot money from the Commonwealth of Independent States (CIS) or former Eastern European countries now economically aligned with Russia, seeking to escape taxation (tax dumping) and financial visibility in their home countries. The inflow of money from the CIS into Baltic correspondent (offshore) banks further juiced the already inflated Baltic property markets with the ensuing rise of commodity prices in 2004 that lasted up to the 2008 downturn. This process built upon trends established with the break-up of the USSR with oligarch export of its natural resource wealth. Artificially high GDP growth based on unsustainable economic sectors (construction in particular), and financed by external liquidity during the boom years 2004-8, created the extraordinary sharpness of the following slump equal to $14-17 \%$ of GDP - one significantly worse than experienced by the EU as a whole (Figure 2). While less sanguine observers had long predicted a 'hard landing,' when it finally arrived in the autumn of 2008, it was unprecedented in scale and depth. As the impacts of the wider global crisis finally cascaded across Eastern Europe in 2008, it was the Baltic states with their liberal and open economies that experienced the sharpest downturns. All three countries experienced punishing economic contractions, with collapsing output, a severe 'correction' in property prices (of up to $60 \%$ of pre-crisis 
nominal values), and rapidly declining average income and consumer consumption levels, as well as widespread unemployment.

As the crisis intensified, the fiscal position deteriorated rapidly and there was a risk of losing access to capital needed to finance growing deficits and to fuel investment. Prevailing monetary policy, with Baltic currencies pegged to the euro currency, did not permit external devaluation as a mechanism for increasing competitiveness (Di Tella et al., 2012), meaning that the Baltic states had little choice but to undertake budget consolidations. 'The fiscal reversal,' at least viewed from Brussels, 'was a significant surprise for all' (Deroose et al., 2010: 6). Fiscal surpluses built up during the boom years and close integration with Finland enabled Estonia to respond somewhat differently to the economic crisis than Latvia and Lithuania. Total general government expenditure was cut by $3-8 \%$ in 2009 and a further $3-7 \%$ in 2010 compared to the previous year (Eurostat, 2012). Thus, general government budget expenditure in 2010 was lower than 2008 's by $10 \%$ in Estonia, $12 \%$ in Latvia, and $7 \%$ in Lithuania.

Government budget consolidation included social welfare reforms aimed at cutting spending and increased taxes. With slight differences from one country to the next, social benefit reforms included reductions and changes to maternity and child allowances and other benefits as overall levels of social protection were reduced (Reeves et al., 2013). The distribution of the cuts put the greatest burden of austerity measures on families with children, as shown by Callan et al. (2011) in Estonia. Cuts in public sector wages, rising unemployment and reduced social benefits were accompanied by increases in taxes. VAT and excise taxes were increased in all Baltic countries, with the VAT going up from $18 \%$ to $21 \%$ in Lithuania and Latvia and from $18 \%$ to $20 \%$ in Estonia. Additionally, Latvian corporate income tax and property tax rates were modestly raised in 2009, but more significantly, the tax-exempt minimum personal income threshold was reduced by almost two-thirds, thereby increasing personal income taxes on their most vulnerable citizens. In Estonia, unemployment insurance contributions were actually raised while the minimum social insurance contribution was also increased.

In Lithuania, the Labour Code was amended to allow easier hiring and firing of employees, reduced or non-payment of severance pay, and extension of working time/part-time employment contracts while, at the same time, there was a significant expansion of the informal economy, facilitating increases in the discretionary power of employers over the workforce in a context of perilously weak trade unions. What appears beyond dispute is that those least able to withstand cuts to living standards (the bottom deciles of household disposable income) shouldered a disproportionate share of the burden of fiscal adjustment due to austerity policies imposed by Baltic governments between the years 2008-2013 (European Commission, 2014: 47).

The economic downturn saw real wages overall declining by 5-8\% in 2009 and $2-6 \%$ in 2010. Nominal wages declined in 2009 in all Baltic countries by up to $5 \%$ and were still declining in 2010 in Latvia and Lithuania. According to national statistical offices, the average monthly wage in 2010 in Estonia was 792 euros, in Latvia 633 euros, and in Lithuania 576 euros. The decline in real wages was largely halted in most of the EU in 2010, in Latvia only by 2011, and in Lithuania by the end of 2012. Thus, both real and nominal wages of those still working during the crisis declined. Coming in the wake of extraordinary wage growth during the boom, the decline of both nominal and real 
wages is an indication of the labour market's extraordinary flexibility, a typical feature of neoliberal capitalism.

In 2009 and 2010, public sector wages were cut more than average private sector wage cuts, dropping by $18 \%$ in 2009 and by a further $9 \%$ in Latvia in 2010, and around half of that in Estonia and Lithuania (Figure 3). Latvia experienced above-average public sector employment cutbacks (20\% in 2010) whereas Estonia and Lithuania only saw minor reductions (Kallaste and Woolfson, 2013). Thus, the public sector, especially in Estonia and Lithuania, absorbed the crisis mainly through wage cuts, while the rest of the economy bore the brunt of job cuts.

Figure 3. Government expenditure on compensation of Employees in Baltic states, 2001-2012

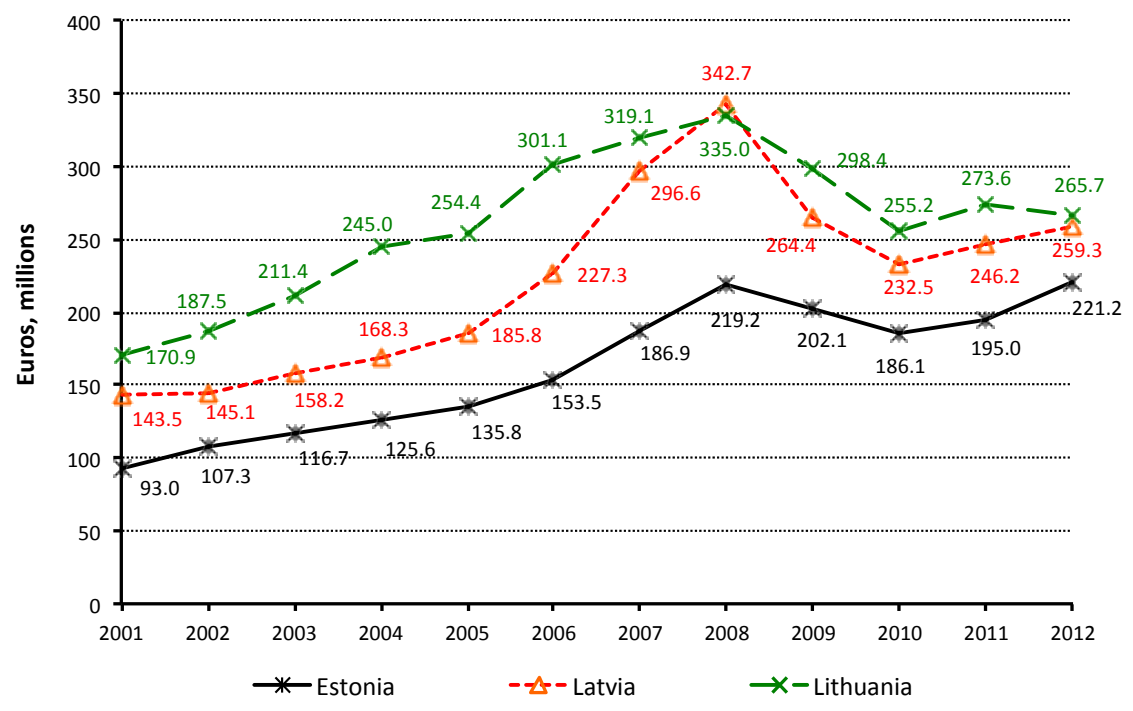

* Source: Eurostat. General government expenditure by function (COFOG) at http:// appsso.eurostat.ec.europa.eu/nui/show.do?dataset=gov_a_exp\&lang=en

An economic shock on such a scale had considerable impact on labour markets. In 2010, official unemployment rates in the Baltic countries were the second-highest in the EU after Spain, reaching 17-19\% (Figure 4). Youth unemployment rates soared to over 30\% in all three Baltic countries. While rates have declined since 2010, this is a function of emigration as discussed below, as significant numbers of the unemployed departed for older EU member states. For those who remained, the share of long-term unemployment in total unemployment was $48.5 \%$ in Latvia in the last quarter of 2013. In Lithuania and Estonia, the share of long-term unemployment was $41.4 \%$ and $40.9 \%$ respectively (SEB, 2014).

As unemployment more than tripled in just two years, the poverty rates also grew significantly, providing an impetus to a new wave of emigration from the Baltic countries. This was especially the case in Latvia and Lithuania. The most recent European Commission report on EU Employment and Social Situation, lists Latvia and Lithuania as having experienced the second and third highest rate of increase in so-called 'anchored' 
poverty rates in 2008-2012 (measured by using a fixed 2008 poverty threshold), correspondingly by $9.1 \%$ and $7.4 \%$ for Latvia and Lithuania, while in Estonia anchored poverty grew by $4.7 \%$ (European Commission, 2014: 41).

Figure 4. Unemployment Rate in Baltic States, 2005-2013

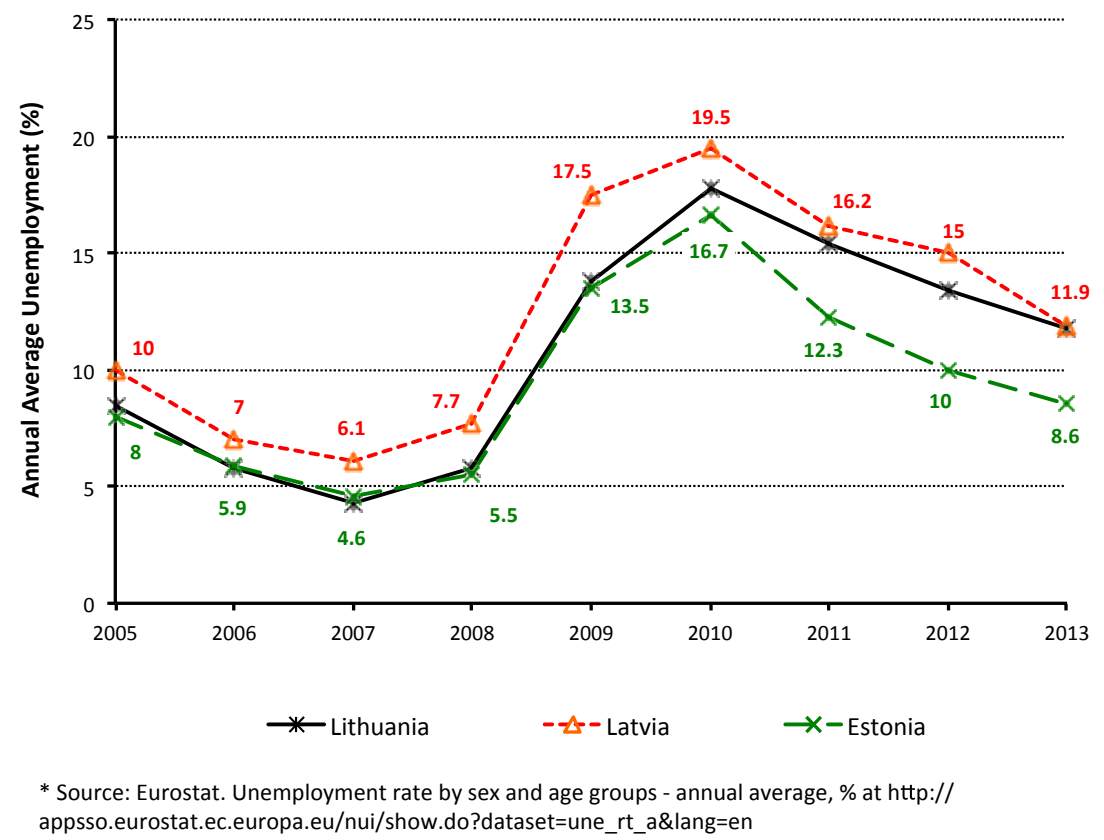

Lithuania and Latvia were at the forefront of EU countries with the highest negative rates of emigration (Figure 5). Thus, in 2010 emigration from Latvia reached -17.0 per 1,000 population, while in Lithuania -25.2 per 1,000 population (although the later number was inflated by changes in Lithuanian emigration registration procedures and is probably close to the one registered in Latvia). Such intensity of crisis-driven emigration looked more like a veritable 'exodus', disproportionately including in its ranks many younger persons and families with small children, threatening depopulation of Baltic countries and demographic sustainability (OECD, 2013). In 2009-2010 alone, emigration reduced the size of Latvia's population by $3.6 \%$ and Lithuania's population by $3.3 \%$ (Latvijas Statistika, 2012; ELTA, 2013). 
Figure 5. Crude rate of net migration plus adjustment from Baltic states, 2004-2013

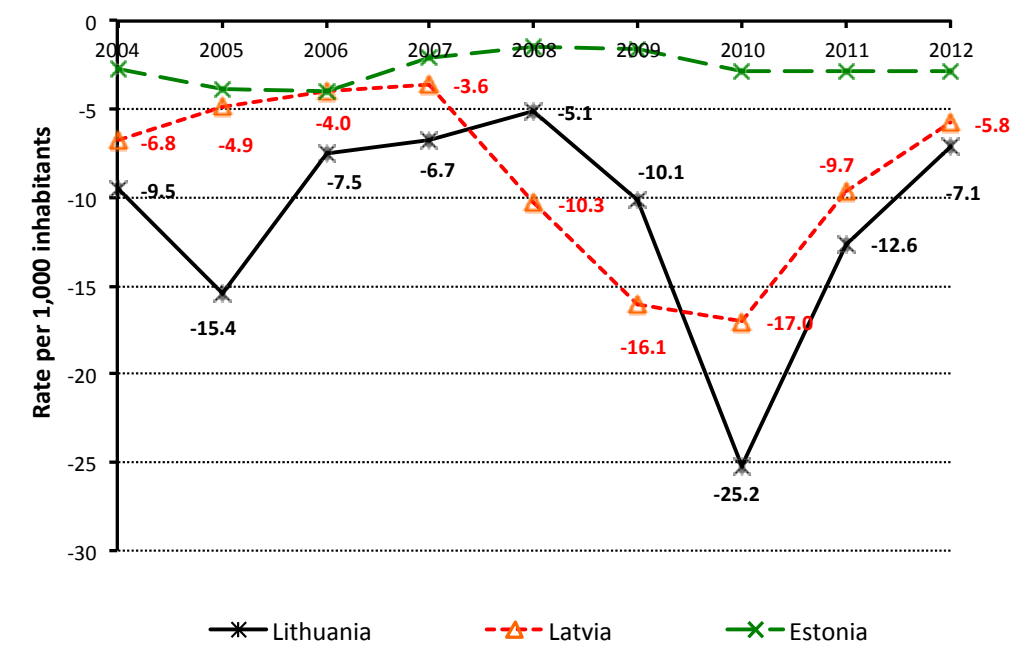

Source: Eurostat. Crude rate of net migration plus adjustment per 1000 inhabitants at http://

epp.eurostat.ec.europa.eu/tgm/table.do?tab=table\&init=1\&language=en\&pcode=tsdde230\&plugin=0

This new austerity-driven migration may be described as comprising an austeriat, a dislocated workforce driven by poverty, unemployment and economic duress which has thrown millions of European citizens out of work since the crash of 2008. 'Free movement' of labour, a much vaunted 'core European value', has in its Baltic incarnation become transmogrified and intensified, whereby Baltic labour migrants seem compelled to use mobility, not so much as an positive opportunity attendant on EU enlargement, but as an economic survival strategy in austere times.

\section{Conclusion: The new hagiography of Baltic austerity}

More fervent still than the EU's belief in the curative powers of austerity, were the Baltic governments', who called for faster and harsher austerity treatments than even the IMF and EU thought prudent (US State Department, 2009). Thus, it was in the most radical neoliberal corner of the 'New' Europe that an austerity experiment was implemented for future trial in the 'Old.' The Baltic austerity strategy was radical in its execution and even more risky in its possible consequences because its costs were disproportionally born by workers and the middle class, as well as those living on a fixed income such as pensioners. Yet it appeared to have succeeded beyond the expectations of its architects, in terms of consolidating budgets and generating economic recovery.

Recovery from 2010 onwards produced GDP growth significantly higher than the EU-27 average, indeed the highest in the EU as a whole, with Latvia's growth at $5.0 \%$ in 2012, followed by Estonia at 3.9\% and Lithuania at 3.7\% compared to $0.4 \%$ for the EU27 (Eurostat, 2013a). Moreover, internal devaluation was largely accomplished without any major long-term opposition. Even though there were protests both big in size and intense in character by trade unions and other groups such as farmers, pensioners and students early on in the crisis, there was little sustained social unrest or concerted public 
opposition to the governments' austerity programs. The seeming paradox of radical austerity but muted social protest is perhaps the most compelling reason why the Baltic experience has attracted appreciable international attention. A vast emigration, in the case of Latvia and Lithuania, and the ability to easily commute to Finland, in the case of Estonia, diluted protests. In the case of Latvia, and somewhat in Estonia, continuing tensions between the titular ethnic Baltic population and ethnic Russians diverted political attention away from austerity as well.

Thus, in light of Greece, Ireland, Italy, Spain, and the United Kingdom's endeavour to produce strong economic recovery through austerity policies, the salience of the Baltic experience has become ever more important. Despite austerity programs of their own devising, many Western and Southern European countries remain in the economic doldrums. By contrast, the Baltics have seen rapid economic growth but in the context of a significant gap in wages with Western or Southern Europe. Indeed, wage levels still remain below those of even Greece where in 2011 average gross annual earnings of full-time employees amounted to 22,240 euros, while in Estonia 11,004, in Latvia 9,065 and in Lithuania a mere 7,269 euros (Countryeconomy.com 2014; Eurostat 2013b). Thus, as a preferred location, the Baltic region has now become a choice for investors seeking comparatively low-cost labour.

Our analysis suggests a warning. Austerity threatens to undermine the basic social fabric and demographic sustainability of the countries subjected to these measures. What transpired in the Baltic states has therefore been of more than local interest. In the larger debate among 'informed analysts' there has been something of a standoff between exponents and opponents of austerity. On the one side, there are those who argue that more austerity measures, as in the Baltics, need to be applied, while on the other, neoKeynesians have argued that modest federal transfers could have kept these economies afloat. As in their response to the populist challenge posed by the European parliamentary elections of May 2014, the single-minded pursuit of the federalist project of Europe's elite is likely to mandate 'More not less Europe.'

At a time when many took the 2008 financial crisis as proof of neoliberalism's failures, the steadfast defence of neoliberalism and promotion of austerity in response by the EC and ECB marked a firm rejection of the Social Europe vision. In the words of Mario Draghi, President of the ECB, 'the European Social Model is gone' (The Wall Street Journal, 2012). The core European Union institutions were to prove rigidly dogmatic in their 'rules based' design and application of prescribed remedies to national governments in terms of the strict requirements for 'reform' and demands for greater 'labour market flexibility' accompanying the subsequent emergency loan packages. By comparison, it was the IMF that was to appear at times a restraining influence on austerity proponents in the Baltic States. Likewise European financial policy-makers in their enthusiasm for labour market reform and fiscal prudence threatened to unleash a tidal wave of social and political unrest in those European countries in which basic social and economic rights as an entitlement were now being summarily removed. Such were the paradoxes of economic crisis management with the singular exception that Baltic policy actors did not anticipate a social backlash of any magnitude (Juska and Woolfson, 2012). The absence of viable popular resistance to austerity may be even more profoundly damaging to the cohesion and sustainability of society in the longer run where 
its population chooses 'exit' rather than 'voice', more so than any temporary disruptions or manifestations of popular democratic disapproval.

The chief reason the Baltic states achieved some economic recovery in the context of a fairly general application of austerity in much of Europe is the convergence issue. Wages in all the Baltic states were considerably below EU averages; thus there was continued investment to take advantage of the wage arbitrage. Other factors are the large transfers from European Union Structural Funds, rescue packages from the EC, and tax dumping via the torrents of offshore money coming from the CIS into Latvia. Increasing agricultural exports, especially of wheat and processed foods, along with timber, have also helped. Given the significant distance yet to travel on wage convergence with EU averages, it is little surprise that the Baltics are continuing their trajectory of economic growth. Even so, by the first quarter of 2014, for the first time since 2010, Estonia had experienced a significant slowdown in GDP growth of $-1.9 \%$ year-on-year, while the accuracy of previously strong Latvian GDP growth figures was publicly disputed (bbn, 2014; nra.lv, 2014). Whether long-term recovery is socially and especially demographically sustainable because of very high and unabating emigration is something that remains in contention.

To sum up, the proponents of the Baltic model claim nearly any crisis country can follow their example. Yet, the small Baltic states have highly distinctive features making it somewhere between impractical to impossible for others to follow. Others seeking to emulate this 'example' would have to meet the conditions:

1 Have a very small population that could permit significant percentages of its population to be absorbed as immigrants by Western European economies. In Latvia and Lithuania about 14\% of the working-age population have emigrated since 2000 (accelerating in 2008 and continuing at high levels until the present, despite economic 'recovery'). Meanwhile, for Estonia, Finland beckoned with a short ferry ride making daily and weekend commutes possible. In short, larger countries would have to export millions of people to follow the Baltic model, or have a wealthy contiguous neighbour willing to take their commuting workers.

2 The nation must be a substantial contagion risk for the EU, IMF, and neighbouring countries to be willing to bail it out. In this case, the Swedish banking system risked a run on deposits in the Baltics and a subsequent crash of their home operations. This posed a contagion risk for Europe's entire banking sector.

3 Banks have to be primarily owned by rich foreign nations, so they can lobby to have EU, IMF, etc., to bail out the crisis nations to ensure banks have their loans paid back. In this case, again, it was Scandinavian banks in the Baltics who were able to apply pressure on the EU and IMF.

4 Ideally, exploitable ethnic divisions should exist to politically divide the population and prevent voting out the pro-austerity party.

5 The country needs to have a relatively depoliticised population (in the Baltics, a legacy from a Soviet past) that, after discouragement from failed popular protests, quietly emigrates rather than continues to protest a government determined to ignore the popular will. 
Few nations meet these highly distinctive criteria to allow the imposition of austerity on this level. It was actually the conjuncture of highly contingent events and a specific history that allowed this radical austerity program to be advanced. As a 'model' for export it is therefore highly problematical. Those contemplating future effects of austerity on heightening tensions in Australian society would do well to consider the exhaustive analysis of the European Trade Union Institute of four years of austerity policies in Europe:

Such a stocktaking exercise reveals, alas, a truly calamitous state of affairs. When economic stability and the confidence of the markets is obtained at the cost of unemployment, precarious living and working conditions and inequality, then political instability can lie only just around the next corner. (ETUI, 2014: 12)

Returning momentarily to the ephemeral discourse of capitalist repentance inaugurated at the May 2014 London conference; in the Australian context where austerity has been defended as a 'fair' public policy on the basis that it establishes 'equality of opportunity' rather than 'equality of outcomes' (Hockey, 2014), the words of Christine Lagarde are especially apposite: 'the problem is that opportunities are not equal...due to current levels of inequality...' (Lagarde 2014). Inequalities, as Piketty's (2014) opus suggests, have been growing rapidly on a global scale. For labour, the Great Financial Crisis has been a trial by dispossession of social and economic gains that were, in the main, won through generations of struggle. The recalibration of labour's socially and politically legitimised expectations by neoliberal austerity as (undeserved) 'entitlements' seems set to provide a terrain of contested interpretations, both of the recent past and of possible alternative near futures.

\section{Acknowledgments}

This article expands on themes in the edited volume J. Sommers and C. Woolfson (2014) The Contradictions of Austerity: The Socio-economic costs of the neoliberal Baltic model. London and New York: Routledge.

\section{Funding}

The authors acknowledge ongoing research funding from the Swedish Research Council for Health, Working Life and Welfare (FORTE) Project Number: 2011-0338.

\section{References}

Amadeo K (2013) National debt by year compared to GDP, recessions and other major events. About.com US Economy. Available: http://useconomy.about.com/od/usdebtanddeficit/a/National-Debt-by-Year.htm (accessed 20 May 2014).

Aslund A and Dombrovskis V (2011) How Latvia Came Through the Economic Crisis. Washington, DC: Petersen Institute.

bbn (Baltic Business News) (2014) Estonian economy shrinks 1.9\% in Q1. 13.05.2014 http://www.balticbusinessnews.com/article/2014/5/13/estonian-economy-shrinks-19-in-q1 (accessed 28 May 2014). 
Bernanke B (2004) Remarks by Governor Ben S. Bernanke at the meetings of the Eastern Economic Association, Washington, DC February 20, 2004, The Great Moderation. The Federal Reserve Board.

Available:http://www.federalreserve.gov/Boarddocs/Speeches/2004/20040220/ (accessed 20 May 2014).

Blyth M (2013) Austerity: The History of a Dangerous Idea. Oxford: Oxford University Press.

Callan T, Leventi C, Levy C, Matsaganis M, Paulus A and Sutherland H (2011) The distributional effects of austerity measures: A comparison of six EU countries. Research Note 2/2011 of the European Observatory on the Social Situation and Demography. www.iser.essex.ac.uk/publications/working-papers/euromod/em611.pdf (accessed 8 August 2013).

Carney M (2014) Speech at the Conference on Inclusive Capitalism, London, 27 May 2014. Available:

http://www.bankofengland.co.uk/publications/Documents/speeches/2014/speech73 1.pdf (accessed 30 May 2014).

Countryeconomy.com (2014) Greece - Average-wage at http: http://countryeconomy.com/labour/average-wage/greece (accessed 28 May 2014).

Cournède B, Goujard A and Pina A (2013) How to achieve growth- and equity-friendly fiscal consolidation? a proposed methodology for instrument choice with an illustrative application to OECD Countries. Economics Department Working Paper No. 1088. Paris: OECD.

Deroose S, Flores E, Giudice G and Turrini A (2010) The tale of the Baltics: Experiences, challenges ahead and main lessons. ECFIN Economic Brief, 10 July. Brussels: European Commission, Directorate-General for Economic and Financial Affairs. Available:

http://ec.europa.eu/economy_finance/publications/economic_briefs/2010/ pdf/eb10_en.pdf (accessed 11 August 2013).

Di Tella R, Abdelal R, and Kindred N (2012) Latvia: navigating the strait of Messina. Harvard Business School, N9- 711-053, March 12. Available: latvia-newyork.org/ english/pdfs/newspdfs/711053_-_Latvia_Navigating_the_Strait_of_Messina_21March2012.pdf (accessed 8 August 2013).

Economist, The (2008) The financial system: What went wrong. 19 March. Available: http://www.economist.com/node/10881318 (accessed May 21, 2014).

ELTA (2013) Lietuvoje mažèja gyventojų [Population in Lithuania continues to decline] Vakaru Ekspresas. Klaipeda, January 9. http://www.ve.lt/naujienos/lietuva/lietuvos-naujienos/lietuvoje-mazeja-gyventoju1887031/ (accessed May 28, 2014)

Emmanuelli H (2005) For the sake of Europe, vote 'No'. Social Europe 1(1): 5-6. ETUI (European Trade Union Institute) (2014) Benchmarking Working Europe 2014. Brussels: European Trade Union Institute.

European Commission (2014) Trends in poverty and social exclusion between 2008 and 2012. EU Employment and Social Situation. Quarterly Review March 2014. Luxembourg: Publications Office of the European Union, pp. 36-41. Available:http://ec.europa.eu/social/BlobServlet?docId=11565\&langId=en (accessed 28 May 2014). 
Eurostat (2012) Economy and finance/National accounts/Annual national accounts/GDP and main components and economy and finance/Government statistics/Government deficit and debt. Subfolders of online database. Available:

http://epp.eurostat.ec.europa.eu/ portal/page/portal/statistics/theme (accessed 15 February 2012).

Eurostat (2013a) Real GDP growth rate-volume: Percentage change on previous year. Available:

http://epp.eurostat.ec.europa.eu/tgm/table.do?tab=table\&init=1\&plugin=1\&languag $\mathrm{e}=\mathrm{en} \& \mathrm{pcode}=\mathrm{tec} 00115$ (accessed 20 October 2013).

Eurostat (2013b) Earnings in the business economy (average gross annual earnings of fulltime employees), 2008-2011. Available:

http://epp.eurostat.ec.europa.eu/statistics_explained/index.php?title=File:Table1_A verage_Gross_annual_Earnings_in_the_business_economy_(full-

time_employees),_2008-2011.png\&filetimestamp=20130619135352 (accessed 28 May 2014).

Flassbeck H (2012) German mercantilism and the failure of the Eurozone. Guest post by Heiner Flassbeck. Yanis Varoufakis, thoughts for the post-2008 world. 12 April. Available: http://yanisvaroufakis.eu/2012/04/21/german-mercantilism-and-thefailure-of-the-eurozone-guest-post-by-heiner-flassbeck/ (accessed 20 May 2014).

Forbes S (2010) Europe's unsung heroes. Forbes Magazine. 8 June. Available: http://www.forbes.com/global/2010/0607/opinions-steve-forbes-lithuaniarecession-fact-comment.html (Accessed 23 May 2014).

Geithner T (2014) Stress Test: Reflections on Financial Crisis. New York: Crown. Glassman J and Hassett K (1999) Dow 36,000. The Atlantic 1 September. Available: http://www.theatlantic.com/magazine/archive/1999/09/dow-36-000/306249/ (accessed 20 May 20 2014).

Gudmundsson M (2008) How might the current financial crisis shape financial sector regulation and structure? Bank for International Settlements. 23 September. Available: http://www.bis.org/speeches/sp081119.htm (accessed 20 May 2014).

Hermann C and Mahnkopf B (2010) Still a future for the European Social Model? Global Labour Journal 1(3): 314-30. Available: http://digitalcommons.mcmaster.ca/globallabour/ vol1/iss3/1 (accessed 10 July 2013).

Hockey J Rt Hon (2014) Speech - A budget for opportunity. Address to the Sydney Institute, 11 June. Available: http://jbh.ministers.treasury.gov.au/speech/009-2014/ (accessed 14 June 14 2014).

Hübner K (2011) Baltic Tigers: The limits of unfettered liberalization. Journal of Baltic Studies 42(1): 81-90.

Jepsen M and Pascual A S (2005) The European Social Model: An exercise in deconstruction. Journal of European Social Policy 15(3): 231-45.

Juska A and Woolfson C (2012) Policing political protest in Lithuania. Crime, Law and Social Change. 57(4): 403-424.

Kallaste E and Woolfson C (2013) Negotiated responses to economic crisis in the Baltic States. Transfer: European Review of Labour and Research 19(2): 253-66.

Krugman P (2012) End This Depression Now! New York: Norton. 
Lagarde C (2014) Economic inclusion and financial integrity - An address to the Conference on Inclusive Capitalism. Guildhall, London, May 27, 2014. https://www.imf.org/external/np/speeches/2014/052714.htm (accessed 14 June 2014).

Latvijas Statistika (2012) Largest population decrease in Latvia recorded in 2009 and 2010. 31 July. Social Statistics Department: Riga. Available: http://www.csb.gov.lv/en/notikumi/largest-population-decrease-latvia-recorded2009-and-2010-35950.html (accessed 28 May 2014).

Lisbon Treaty, The (2008). Official Journal of the European Union, C 115, Volume 51., 9 May . http://www.lisbon-treaty.org/wcm/the-lisbon-treaty/treaty-on-thefunctioning-of-the-european-union-and-comments/part-3-union-policies-andinternal-actions/title-viii-economic-and-monetary-policy/chapter-1-economicpolicy/391-article-123.html (accessed May 29, 2014).

Lopez K (2013) Thatcher matters. The National Review 8April. Available: http://www.nationalreview.com/corner/345024/thatcher-matters-kathryn-jean-lopez (accessed 19 May 2014).

Myrdal G (1990) The Political Element in the Development of Economic Theory. New Brunswick, NJ: Transactions Publishers.

nra.lv (2014) Lielie meli un Latvijas statistika. (The big lie and Latvian statistics). 19 May Available: http://nra.lv/viedokli/juris-paiders-3/117537-lielie-meli-un-latvijasstatistika.htm (accessed 28 May 2014).

OECD (Organisation for Economic Cooperation ad Development)(2013) Coping with Emigration in Baltic and East European Countries. OECD Publishing. Available: http://dx.doi.org/10.1787/9789264204928-en (accessed 28 May 2014).

Office of Management \& Budget of the White House of the United States (2014) Historical tables. Table 7.1. Available: http://www.whitehouse.gov/omb/budget/historicals (accessed 29 May 2014).

Panitch L (2009). Thoroughly modern Marx. Foreign Policy 15 April 15. Available: http://www.foreignpolicy.com/articles/2009/04/15/thoroughly_modern_marx (accessed May 18, 2014).

Panitch L and Gindin S (2012) The Making of Global Capitalism: The Political Economy of American Empire. London: Verso Books.

Piketty T (2014) Capital in the $21^{\text {st }}$ Century. Cambridge, MA: Belknap Press.

Reeves A, Basu S, McKee M, Marmot M and Stuckler D (2013) Austere or not? UK coalition government budgets and health inequalities. Journal of the Royal Society of Medicine. OnlineFirst 11 September. Available: doi:10.1177/0141076813501101 (accessed 28 May 2014).

Reinhart C and Rogoff K (2010) Growth in a time of debt. American Economic Review: Papers \& Proceedings 100 May: 573-8. Available:

http://scholar.harvard.edu/files/rogoff/files/growth_in_time_debt_aer.pdf (18 accessed May 2014).

Ryan P (2012) The Path to Prosperity: A Blueprint for American Renewal, March 20, Washington, D.C.: US House of Representatives. http://budget.house.gov/uploadedfiles/pathtoprosperity2013.pdf (accessed 11 May 2014). 
SEB (2014) Baltic household outlook, April. Available:

http://www.seb.ee/sites/default/files/web/files/uudised/BHO_aprill2014.pdf (29 accessed May 2014).

Sommers J (2011) Euro SOS. Crosstalk 11 September 11. Available:

http://rt.com/shows/crosstalk/ euro-eurozone (accessed July 31, 2013).

Sommers J and Woolfson C (eds) (2014) The Contradictions of Austerity: The socioeconomic costs of the neoliberal Baltic model. London and New York: Routledge.

Song W (2011) Open method of coordination and the gloomy future of Social Europe. Asia Europe Journal 9(1): 13-27.

Stone C, Trisi D, Sherman A and Tren W (2014) A guide to statistics on historical trends in income inequality. Center on Budget and Policy Priorities 17 April 17. Available: http://www.cbpp.org/cms/?fa=view\&id=3629 (accessed 21 May 2014).

Streeck W (2011) The crisis of democratic capitalism. New Left Review 71: 5-29.

US State Department (2009) 09STOCKHOLM678, Swedish views of Latvia's 2010 budget proposal. WikiLeaks October. Available:

http://wikileaks.org/cable/2009/10/ 09STOCKHOLM678.html (accessed 10 February 2013).

Varoufakis Y (2011) The Global Minotaur: America, the True Origins of the Financial Crisis and the Future of the World Economy. London: Zed Books.

Wall Street Journal, The (2012) Europe's banker talks tough. Draghi Says continent's Social Model is 'gone,' won't backtrack on austerity. 24 February. Available: http://online.wsj.com/news/articles/SB100014240529702039608045772412212448 96782 (accessed 29 May 2014).

Whyman P Bambridge M and Mullen A (2012) The Political Economy of the European Social Model. London: Routledge.

Wood R (2013) Europe: The failure of internal devaluation. EconoMoniter 13 November. Available: http://www.economonitor.com/blog/2013/11/europe-the-failure-ofinternal-devaluation/ (accessed 19 May 2014).

\section{Author biographies}

Jeffrey Sommers is Associate Professor of Political Economy and Public Policy in Global Studies \& Africology at the University of Wisconsin-Milwaukee. He is also Visiting Faculty, Stockholm School of Economics in Riga.

Charles Woolfson is Professor of Labor Studies at the Institute for Research on Migration, Ethnicity, and Society (REMESO), Linköping University, Sweden. He has been a resident Marie Curie Chair at the former EuroFaculty, University of Latvia.

Arunas Juska is Associate Professor of Sociology at East Carolina University, USA. He writes extensively on the Baltic region, with special focus on rural development and policing in Lithuania. 